- decision-making bodies, he says. "Until the structures change, there won't be significant change."

The report proposes that UCT reforms recruitment processes to make them more transparent and inclusive, and that its policies addressing discrimination such as racism and sexism be "effectively and adequately implemented". It also recommends that the university strengthens mental-health services for students and staff, and revises its affirmativeaction admission policies for black students.

UCT's leadership said in a statement to Nature that it would respond to the report's recommendations after a committee had considered the recommendations and reported to the university's council; that is scheduled for June. In the statement, it acknowledged that the protests had raised "very serious challenges" and that "many lessons were learnt".

\section{CAMPUS PROTESTS}

The university set up the UCT Institutional Reconciliation and Transformation Commission after the $2015-16$ protests. These were part of nationwide campus demonstrations in which students demanded an end to tuition fees and called for a 'decolonized' curriculum - one that eliminates, or minimizes, the disproportionate legacy of white European thought in academic programmes.

The protests started at UCT and began with calls for a prominent statue of British colonial businessman and politician Cecil Rhodes to be removed from the university's main campus. Later, protesters disrupted lectures and exams at the university, occupied buildings and destroyed property. UCT paid a private security company to protect its staff and property - which protesters and some staff members described as counterproductive.

Mosibudi Mangena, a former South African science minister, led the commission, which

also featured a human-rights lawyer and a retired constitutional-court judge. It drew on 80 submissions from students and staff members, as well as from institutional hearings for students who had been involved in the most destructive protests. The report concludes that racism exists at UCT, "abetted by poor management systems" which "discriminate on a racial basis".

Robert Morrell, a social scientist who leads a UCT programme that addresses demographic inequalities among mid-career academics, questions whether 80 sources are enough to conclude that UCT is racist. "What about the

"Until the structures change, there won't be significant change." other 30,000 students, 4,000 staff and the tens of thousands of alumni?" he wrote in a 1 April opinion piece for the Daily Maverick online newspaper.

Racial transformation of historically white-dominated universities has been high on South Africa's agenda since apartheid ended in the early 1990s. But although all institutions have policies aimed at raising the proportion of black staff and assisting disadvantaged students, many people feel that progress in implementing them has been slow.

\section{CURRICULUM CHANGE}

Mamokgethi Phakeng, who became UCT's vice-chancellor in mid-2018, has prioritized campaigning for inclusivity and racial transformation. She has introduced targeted scholarships for women and postgraduates, and has cleared some students' debt to help them graduate. But her vision will filter down to department level only if middle management comes on board, says Amanda Weltman, a cosmologist at UCT. "Some feel inclusivity is a threat," she says, and weak management can be a major obstacle to progress, she adds.

The report is likely to fuel tensions surrounding efforts to decolonize UCT's academic programmes. In 2016, the university tasked a working group with creating a Curriculum Change Framework to guide this work. The framework was published in 2018, and sets out the need to forge a new identity for UCT that regards Africans as "legitimate knowers and producers of knowledge" who are central to the academic project. It says that previously disregarded texts should become core reading material for students, that people from marginalized communities should become drivers of research, and that "colonial lies embedded in disciplines, must be exposed and disrupted".

"Central in resisting coloniality is defying colonial authority in what constitutes knowledge, how it is produced, and who is allowed to claim custodianship," the framework states. It is especially difficult to challenge authority in the sciences, it says, and resistance from gatekeepers is acute.

UCT staff members are being consulted about the framework, which could guide future curriculum reform. It already has critics: in February, four UCT academics said that it threatens academic freedom and that if the framework became policy, it might dismiss curricula informed by "humankind's most reliable methods of evidence-gathering and investigation" as "colonial ideology". Chinyoka says that these fears are "knee-jerk responses".

South African universities must strike a balance between radical change and safeguarding excellence, says Brenda Wingfield, a molecular biologist at the University of Pretoria. "We need to be very careful about keeping the functional universities that we have," she says. Universities must inspire young Africans to be passionate about Africa, she adds. "But we also need to teach global citizens, not blinkered nationalists who cannot see beyond our borders."

\title{
Australian budget fails to impress
}

\section{Science shunned in this year's spending proposal.}

\section{BY SMRITI MALLAPATY}

A ustralians are just weeks from a national election, and the government's latest budget proposal, released on 2 April, prioritizes tax cuts, roads and small businesses ahead of spending on science. Projects in nuclear medicine, environmental protection and gender equality in science received modest investments. But there was no new money for research grants, and universities would be worse off under the proposal.

"It is not an inspirational budget for a nation that needs to transition from a bulk resources exporter to an innovation economy," says Sydney-based marine ecologist Emma Johnston, president of Science \& Technology Australia (STA), an umbrella organization of societies that represent a total of 70,000 researchers.

Ultimately, whoever wins the election in mid-May will determine the final budget. If the ruling conservative coalition returns to power, over the next four years universities will lose Aus $\$ 345$ million (US\$245 million) that had been earmarked in previous budgets to pay for costs not covered by research grants, such as training, electricity and salaries for technical staff. The drop in funding follows a series of cuts

Australian treasurer Josh Frydenberg. 
to to universities' budgets over several years.

"The government has missed an important opportunity to reverse economydamaging cuts to university funding, and secure economic growth," says environmental chemist Dianne Jolley at the University of Technology Sydney.

The latest budget does not include more money for the two major research funding agencies - the Australian Research Council and the National Health and Medical Research Council - beyond keeping pace with inflation over the next four years. Neither does it provide a funding boost beyond inflation for the Commonwealth Scientific and Industrial Research Organisation.

Scientists are disappointed that the government has not met the STA's request to allocate money to create an investment fund for non-medical science. In 2015, the government set up a Medical Research Future Fund to invest an estimated Aus $\$ 1$ billion a year in translating and commercializing basic medical research by 2020 . Treasurer Josh Frydenberg says the fund is on track to raise Aus $\$ 20$ billion by 2020-21. A complementary fund for non-medical research would support the experiments needed to translate scientific discoveries into products or services, says Johnston.

The few winners in science include nuclear-medicine research, with Aus $\$ 56.4$ million for the Australian Nuclear Science and Technology Organisation over three years. Another Aus $\$ 25$ million over four years will be provided to Monash University and the University of Melbourne to set up a coastal, environmental and climate research centre near Melbourne.

"An investment in coastal science is long overdue," says marine scientist Ruth Reef, who heads the Coastal Research Group at Monash. Coastal habitats are increasingly affected by intensive agriculture, urbanization, sea-level rise and storms, says Reef. Further interdisciplinary research is needed to protect these habitats and improve their management, she says. "Perhaps no habitat is more at risk than the coastal zone."

The government also plans to allocate Aus $\$ 3.4$ million over four years to support women in science, technology, engineering and mathematics. The money includes Aus $\$ 1.8$ million for the Science in Australia Gender Equity initiative to attract and retain women in science, which is modelled on the Athena SWAN Charter, a UK higher-education accreditation programme. "Anything is better than nothing, but ten times that amount would have been good," says geneticist Jennifer Graves at La Trobe University in Melbourne.

The small win, she says, will not make up the shortfall from broader, ongoing funding cuts that have reduced universities' capacity to create a healthy academic environment for scientists, especially women.

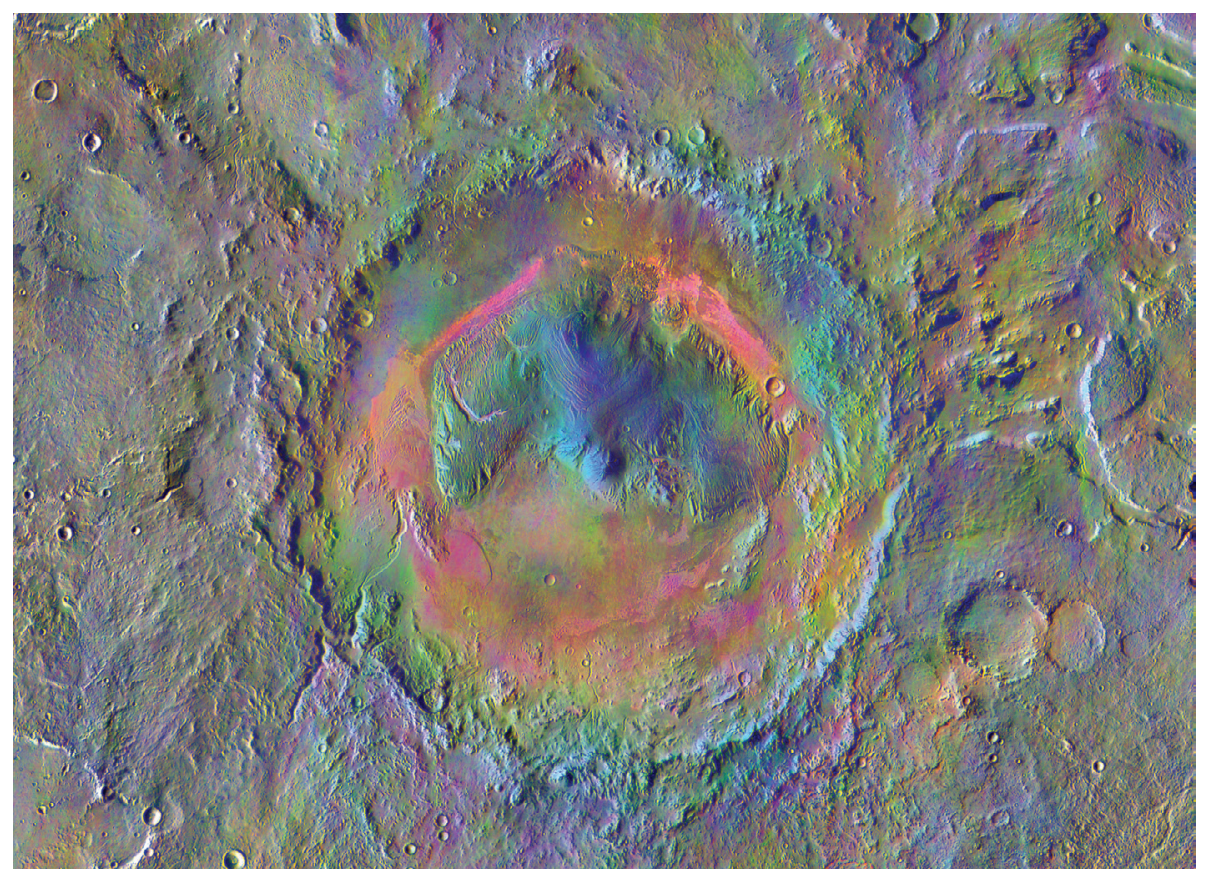

Gale crater (shown in false colour) is where NASA's Curiosity rover has detected methane.

PLANETARY SCIENCE

\title{
Mars data deepen methane mystery
}

\author{
The Trace Gas Orbiter did not find the gas in Mars's \\ atmosphere during its first months of operation.
}

\section{BY ALEXANDRA WITZE}

A spacecraft that was supposed to solve the mystery of methane on Mars has instead compounded scientists' confusion. The European-Russian Trace Gas Orbiter (TGO), which began looking for the gas last year, has yet to find any whiffs of it in Mars's atmosphere, researchers report this week in Nature ${ }^{1}$.

"It's a huge surprise," says Dorothy Oehler, a planetary geologist at the Planetary Science Institute in Houston, Texas.

Earlier Mars missions have detected hints of methane wafting through the atmosphere. The TGO's failure so far to find the gas suggests that an unknown process is scrubbing much of it from the atmosphere soon after it appears, says Oleg Korablev, a physicist at the Space Research Institute in Moscow and lead author of the study.

Planetary scientists are keen to understand where Martian methane comes from because most methane in Earth's atmosphere is formed by living organisms. Pinning down how much methane is in Mars's atmosphere, and where, would help researchers to determine whether the gas comes from geological sources, such as chemical reactions in rocks, or a more exciting origin - potentially, Martian life.

Scientists have repeatedly spotted methane on Mars over the past 15 years. The reports include telescopic views of a gas plume in 2003 (ref. 2) and, since 2012, occasional detections by NASA's Curiosity rover at Gale crater ${ }^{3}$. The European Space Agency's Mars Express spacecraft has spotted the gas at multiple sites including a plume near Gale in 2013 (ref. 4).

Aiming to answer the question more definitively, the TGO arrived at Mars in 2016. It began collecting atmospheric data in April 2018. Between April and August of 2018, it found no signs of methane, even though its instruments can detect the gas at concentrations below 50 parts per trillion.

Curiosity sniffed about 500 parts per trillion of methane in mid-June 2018 - at the same time that the TGO flew overhead without seeing any, says Christopher Webster at the Jet Propulsion Laboratory in Pasadena, California, who runs the rover's methane-measuring instrument. Models suggest that any methane plumes should drift upward and mix 